Article accepted for publication with Vetus Testamentum.

HÊLEL BEN-ŠAHAR AND THE CHTHONIC SUN:

A NEW SUGGESTION FOR THE MYTHOLOGICAL BACKGROUND OF ISA 14:12-15

This paper will explore the oft investigated problem of the mythological referents which inform Isa 14:12-15. Crucial to this will be a reinterpretation of the mysterious hêlēl ben-šaḥar of v. 12, almost universally understood by commentators and translators alike to refer to the 'Day Star, son of the Dawn', and thus taken to refer to the 'morning star', the planet Venus. Much of the scholarship has approached the ancient Near Eastern material with this meaning in mind, yet no myth hitherto proposed has provided a complete analogy to Isa 14:12-15. Thus I will begin by exploring the problems with these previous analogies, before reconsidering the meaning of hêlēl ben-šahar. Understanding the phrase to metonymically remind of the sun itself, the Ugaritic conception of the chthonic sun will be proposed to provide a much more satisfying parallel with our Isaiah passage.

Keywords: Isaiah 14:12-15; hêlēl ben-šaḥar; Ugarit; Šapaš; Underworld 
Article accepted for publication with Vetus Testamentum.

\section{HÊLEL BEN-ŠAHAR AND THE CHTHONIC SUN: A NEW SUGGESTION FOR THE MYTHOLOGICAL BACKGROUND OF ISA 14:12-15}

The problem of the poem of Isa 14:12-15, part of the larger literary complex of Isa $14: 4 \mathrm{~b}-20,1$ that has garnered the most scholarly attention is the particular mythological referents implied by the language and ideas present in this enigmatic section of text. These attempts to pinpoint the exact extra-biblical context of the poem have often been complicit with the distinction posited in much of earlier scholarship between the religions of the ancient Near East against that of the ancient Israelites, and the view that the writers of the Old Testament 'demythologized' the 'nature religions' of their Near Eastern neighbours: while Yahweh acted in history, the gods of the rest of the ancient world could act only in nature. Alternatively this was expressed as a difference between 'linear' and 'cyclic' conceptions of time. ${ }^{2}$ In the case of Isa 14:12-15, a particular mythological background was adduced, before a historical circumstance could be superimposed upon the narrative; thus the Hebrew authors had utilized a mythological trope only in order to subvert it by applying such fantastical metaphors, usually of a 'seasonal myth', to a historical situation and personage. ${ }^{3}$ Accordingly, while in its present position the poem can be linked to a Babylonian ruler only in a secondary way by the framing vv. 3-4a and 22-23, and not by any particular historical link in the text itself - commentators have often tried to map this material onto the career of a

\footnotetext{
${ }^{1}$ This description of the downfall of a world leader and of Babylon can be marked off from the surrounding material on both formal and metrical grounds. Employing the qînāh meter characteristic of the lament (e.g. 2 Sam 1:19, 25; 27; cf. already H. Jahnow, Das hebräische Leichenlied im Rahmen der Völkerdichtung [BZAW, 36; Giessen, 1923], p. 231), the unit is recast, in the words of 0 . Eissfeldt, as a 'mocking prophetic funerary dirge' (0. Eissfeldt, The Old Testament: An Introduction [Oxford, 1965], p. 96). Within the unit 14:4b-20, vv. $4 \mathrm{~b}-11$ and 12-21 can be further divided into two separate poems (J. Blenkinsopp, Isaiah 1-39: A New Translation with Introduction and Commentary [New Haven, 2000], p. 285), brought together by the similarity between each composition's theme of hubris and by the end destination for the arrogant referent in each, šs'ôl.

${ }^{2}$ For this type of approach see especially G. von Rad, 'The Theological Problem of the Old Testament Doctrine of Creation', in The Problem of the Hexateuch and Other Essays (London, 1966), pp. 131-143.

${ }^{3}$ For example W. Bruggemann, Isaiah 1-39 (Louisville, 1998), pp. 128-129: 'Now comes a long poetic section that ponders and celebrates the astonishing reversal that occurs in the historical process. The reversal happens in the historical process, and one can, of course, identify "historical" reasons and agents for the fall of an abusive superpower.'
} 
Article accepted for publication with Vetus Testamentum.

particular Babylonian king. Others, noting that the status of Babylon in the eighth century would see a Babylonian referent unlikely if Isaianic authorship was to be defended, have preferred an Assyrian king; while still others have named Alexander the Great as a possible later referent. ${ }^{4}$

More recently however, the impossibility of correctly identifying the figure in question, as the multitude of possible suggestions imply, has been stressed. Indeed, the very ambiguity of the passage and the real lack of tangible historical links that it makes has made it possible for readers to reactualize the text again and again in the context of new historical circumstances. ${ }^{5}$ In this paper I shall argue that this dehistoricization of the passage can be similarly linked to a demythologization of the 'nature myth' which has commonly been posited as its ancient forebearer - indeed, the seasonal myth trope does not fit particularly well with the Isaiah pericope after all. Instead, an alternative ancient Near Eastern parallel will be posited. Crucial to this is a reinterpretation of the mysterious hêlēl ben-šaḥar of v. 12, almost universally understood by commentators and translators to refer to the 'Day Star, son of the Dawn',6 and thus taken to refer to the 'morning star', the planet Venus. Much of the scholarship has approached the ancient Near Eastern material with this meaning in mind, yet no myth hitherto proposed has provided a complete analogy to Isa 14:12-15. Thus I will begin by exploring the problems with these previous analogies, before reconsidering the meaning of hêlel benšạar. Understanding the phrase to metonymically remind of the sun itself, the Ugaritic conception of the chthonic sun will be proposed to provide a much more satisfying parallel with our Isaiah passage.

\section{Mythological Parallels to Isa 14:12-15}

Three major possibilities for the mythological referents of Isa 14:12-15 have typically been posited: (i) the Greek Phaëton myth; (ii) the Ugaritic myth of the god 'Attar from the so-called Ba'al cycle; and (iii) the Akkadian myth of Ištar's Descent to the

\footnotetext{
${ }^{4}$ On the history of scholarly interpretation of this passage, see R.M. Shipp, Of Dead Kings and Dirges: Myth and Meaning in Isaiah 14:4b-21 (Leiden, 2002), pp. 1-31.

${ }^{5}$ See e.g. H. Wildberger, Isaiah 13-27: A Continental Commentary (trans. T.H. Trapp; Minneapolis, 1997), p. 54. It is notable that the referent of v. 4 is called a $n g s$, 'despot', and a mrhb, 'tyrant', but not specifically a $m l k$, 'king'.

${ }^{6}$ ESV, RSV, ASV, and NRSV supply 'Day Star, son of the Dawn'; NIV prefers 'morning star', with the same semantic implication.
} 
Article accepted for publication with Vetus Testamentum.

Netherworld, the latter in particular complicit with the 'nature myth' interpretation.7 Drawing on suggestions of earlier scholars, ${ }^{8} \mathrm{P}$. Grelot was the first to fully explore the theory that (i) the Greek myth(s) of Phaëton may be associated with Isa 14:12-15, although he did posit a now lost Canaanite intermediary between the Greek and Hebrew conceptions of the tradition. ${ }^{9}$ Accepting the interpretation of hêlēl ben-šahar as the planet Venus, Grelot drew from several pools of Greek mythology associated with the figure $\varphi \alpha \varepsilon \dot{\varepsilon} \theta \omega$, Phaëton. In Homer, Phaëton was the name of one of the horses that pulled the chariot of Eos (Od. 23.275); in Hesiod Phaëton was the son of Eos, and this name may also refer to Venus (Theog. 986). Elsewhere in Greek mythology another Phaëton, son of Helios and Klymene, was said to have unsuccessfully tried to drive the chariot of the sun through the clouds, causing Zeus to intervene and strike the chariot

\footnotetext{
${ }^{7}$ Several other Mesopotamian texts and deities have been proposed to provide possible parallels to the Isaiah text: e.g. the flood account of tablet XI of the Epic of Gilgamesh (see R.C. Van Leeuwen, 'Isa. 14:12, hôlēšs 'al gwym and Gilgamesh XI, 6', JBL 99 [1980], pp. 173-184; and R.H. O'Connell, 'Isaiah XIV 4B-23: Ironic Reversal through Concentric Structure and Mythic Allusion', VT 38 [1988], pp. 407-418); the Akkadian god Illil, in Sumerian known as Enlil (W.R. Gallager, 'On the Identity of Hêlēl ben Šaḥar of Isa. 14:12-15', UF 26 [1994], pp. 131-146); while S.H. Langdon, 'The Star Hêlēl, Jupiter?', ExpTim 49 (1931), pp. 172-174, points to parallels with the Babylonian myth šar gimir dadmê, better known as the Myth of Erra, in which the plague god attempts to destroy the world. Despite Leeuwen's argument that Isa 14:12-15 contains 'intentional' parallels to the Gilgamesh Epic, arguably in both the case of the Epic, and of the Erra Myth, such parallels are both non-literalistic and non-linear; while the deity Illil does not provide a similar mythological narrative to Isa 14:12-15, despite the resemblance which Gallager posits between the Hebrew hapax hêlel and the Akkadian god-name Illil. None of these proposals really provides secure analogy to the Isaiah text.
}

8 The Phaëton myth had previously been proposed by H. Gunkel, Schöpfung und Chaos in Urzeit und Endzeit: eine religionsgeschichtliche Untersuchung über Gen 1 und Ap Joh 12 (Göttingen, 1895), p. 133; N.A. Koenig, 'Lucifer', ExpTim 18 (1907), p. 479; and B. Duhm, Das Buch Jesaja (Göttingen, 1914), although these scholars forwarded their proposals before the discovery and wider dissemination of the Ras Shamra texts.

${ }_{9}^{9}$ P. Grelot, 'Isaïe XIV 12-15 et son arrière-plan mythologique', RHR 149 (1956), pp. 18-48. In subsequent literature, Grelot's Greek context for the Isaiah myth has been affirmed by e.g. 0 . Loretz, 'Der kanaanäisch-biblische mythos vom Sturz des Sturtz des Šahar-Sohnes Hêlēl (Jes 14, 12-15)', UF 8 (1976), pp. 133-135; W.G.E. Watson, 'Helel הליל', in K. van der Toorn et al. (eds.) Dictionary of Deities and Demons in the Bible (Leiden, 1995), pp. 746-750; J.C. Poirier, 'An Illuminating Parallel to Isaiah XIV 12', VT 49 (1999), 371-389; and Blenkinsopp, Isaiah 1-39, p. 288. 
Article accepted for publication with Vetus Testamentum.

back down to the ground with a rod of lightening. ${ }^{10}$ By conflating this second Phaëton with the first, the Phaëton associated with Venus, Grelot was able to provide affinities and analogies to Isa 14:12-15, in as much as this too (may) refer to Venus and depicts an arrogant act and subsequent fall. But nevertheless the conflation of these two myths does not provide particularly strong parallels. Grelot had to work hard to provide a viable Greek myth, synthesizing two separate traditions that individually would not provide robust associations with our Isaiah text. Part of the reason for his identification rested on understanding hêlēl ben-šaḥar as the planet Venus which, as we shall see below, is by no means certain; moreover in stealing the chariot the second Phaëton does not seem to have wanted to establish himself above other gods, and nor was he cast down to the depths of the underworld following his transgression. Grelot felt the need to posit a hypothetical Canaanite intermediary to account for the alleged similarities between the Phaëton myths and Isa. 14:12-15, although later scholars were by no means so cautious. ${ }^{11}$ Part of the problem here is the trajectory of transmission from Greek to Hebrew ideas - usually Greek mythology is understood as having had Near Eastern antecedents, and not vice versa.

Affinities between Ugaritic and Hebrew ideas are less controversial, and so following the discovery of the Ras Shamra texts scholars were quick to assert Ugaritic parallels to the Isaiah passage. In favour of the Ugaritic interpretation are a number of referents in the text of Isa 14:12-15 that seem to make use of Ugaritic tropes and ideas. In particular note vv. 13-14:

${ }^{13}$ we'attâ 'āmartā bilebābekā haššãmayim 'ee lêe ${ }^{13}$ You said in your heart, 'I will ascend to mimma'al lekôkebê-'él 'ârîm kis'î we'ēšêb behar- heaven; above the stars of 'El I will set my mô'ēd beyarketê șāpôn throne on high; I will sit on the mountain of assembly, in the remote parts of Zaphon;

14 'e'eleh 'al-bomotê 'äb 'eddammê le'elyôn ${ }^{14}$ I will ascend above the heights of the clouds; I will make myself like 'Elyon.'

\footnotetext{
${ }^{10}$ Grelot, 'Isaïe XIV 12-15 et son arrière-plan mythologique', pp. 30-32.

${ }^{11}$ Thus while N. Ayali-Darshan, 'The Role of Aštabi in the Song of Ullikummi and the Eastern Mediterranean "Failed God" Stories', JNES 73 (2014), pp. 95-103, connects the apparent appearance of the myth in Ugaritic, Hebrew and Greek literatures to a general mythic topos of the 'failed god' in the Eastern Mediterranean, other scholars such as W. Baumgartner, Zum Alten Testament und seiner Umwelt: Ausgewälte Aufsätze (Leiden, 1959), p. 157; and J.W. McKay, 'Helel and the Dawn-Goddess: A Re-Examination of the Myth in Isaiah XIV 12-15', VT 20 (1970), pp. 451-464, have simply posited a direct Greek to Hebrew connection.
} 
Article accepted for publication with Vetus Testamentum.

Here a number of items that suggest associations to the corpus of Ugaritic literature are found. The use of 'êl, which can be translated as 'God' but might also reflect a personal name, the head of the Ugaritic pantheon 'El, especially given that 'elyôn, "Elyon, the Most High', follows. The mô'éd, 'meeting place', suggests an assembly of the gods in the terms of a Ugaritic phr m'd, 'group of the assembly';12 while șāpôn, 'Zaphon', is the sacred mountain of the storm-god of Ugaritic religion, Ba'al - and certainly bomotê 'âb, 'the heights of the clouds', suggests imagery typical of the storm god, rider of the clouds. ${ }^{13}$ However these associations are rather muddled, mixing imagery usually associated with Ba'al (Zaphon, the heights of the clouds) with personal names usually applied to the head of the pantheon, 'El.14 That there is no obvious parallel here to motifs associated with any one Ugaritic deity is correlated by the difficulty that scholars seem to have had to come up with a satisfactory precursor from Ugaritic tradition to Isa 14:12-15. While many scholars seem happy merely to point out a general Ugaritic background to our Isaiah passage, 15 others have made attempts to find a specific Ugaritic Vorlage. Most commonly proposed is (ii) the Ugaritic myth of the god 'Attar, which appears as part of the Ba'al cycle. By accepting that hêlēl ben-šaḥar must refer to the planet Venus, the

${ }^{12}$ Already suggested by O. Eissfeldt, Baal Zaphon, Zeus Kasios und der Durchzug der Israeliten durchs Meer (Halle, 1932), p. 14.

${ }^{13}$ That the rather difficult term $r^{e} p \bar{a}^{\prime} i ̂ m$ precedes our passage in v. 9 might also suggest a Ugaritic relation, given the mythological creatures called rp'um found in the Ugaritic texts (see e.g. J. Gray, 'The Rephaim', $P R Q 79$ [1949], pp. 127-139; C. L'Heureux, 'The Ugaritic and the Biblical Rephaim', HTR 67 [1974], pp. 265-274; J.C. de Moor, 'Rāpi'ūma - Rephaim', ZAW 88 [1976], pp. 323-345; and J. Day, Yahweh and the Gods and Goddesses of Canaan [JSOTSupp., 265; Sheffield, 2000], pp. 217-225). Nevertheless this association is uncertain, especially given the ambiguity of the use of repa'îm in the Hebrew Bible: sometimes seeming to suggest the inhabitants of the underworld as here and in Isa 26:19; Job 26:5; Prov 2:18; 9:18; 21:16; and in Isa 26:14 and Ps 88:11, where it parallels mètīm, 'the dead' (cf. also KAI 13:8 and 14:8, two Phoenician coffin inscriptions which bear the term); and sometimes seeming to refer to a legendary population group that inhabited Palestine prior to the emergence of Israel in the land (Gen 14:5; 15:20; Deut 2:11, 20; 3:11; Josh $12: 4 ; 17: 15)$.

${ }^{14}$ Although see Psalm 29.

${ }^{15}$ For example, W.F. Albright, 'The North Canaanite Poems of 'Al'eyan Ba'al and the Gracious Gods', JPOS 14 (1934), pp. 101-140; idem, Archaeology and the Religion of Israel (Baltimore, 1942), pp. 84, 86; B.S. Childs, Myth and Reality in the Old Testament (London, 1960); R.E. Clements, God and Temple (Oxford, 1965), p. 7; and R.J. Clifford, The Cosmic Mountain in Canaan and the Old Testament (HSM, 4; Cambridge, 1972), pp. 160-168. 
Article accepted for publication with Vetus Testamentum.

Ugaritic god 'Attar, who in South Arabian inscriptions is referred to as Venus, ${ }^{16}$ may be forwarded as a possible Ugaritic counter to the ambiguous Hebrew phrase. Following the apparent death of Ba'al in the underworld, 'Attar assumed Ba'al's throne, finding it to be too large for him. He subsequently abandoned it and descended to rule the earth instead. To propose that this tale parallels that of Isa 14:12-15 requires a number of interpretative decisions that rely on a particular reading of this episode of the Ba'al cycle: according to N. Wyatt, 'Attar's attempted reign should be viewed negatively as an usurpation and that following this he was forced to vacate his throne by 'El.17 This recasts the episode as an act of hubris on the part of 'Attar in common with the Isaiah description, to the extent that M.S. Heiser could proclaim that 'all the elements of the Taunt-song [Isa 14:12-15] can be related to the Ba'al-'Athtar myth'.18 And yet this is an interpretation of the Ba'al cycle that is not prima facie available from the text itself: as $K T U^{3}$ 1.6.1.43-46 makes clear, 'Attar was chosen to succeed Ba'al on the suggestion of 'Atirat - his royal claim was not an act of hubris. In the words of D. Pardee, while Ba'al and Yamm appear to be competing for the same kingship, 'Attar 'exercises kingship in his own way and in his own sphere.'19

\footnotetext{
${ }^{16}$ See U. Oldenburg, 'Above the Stars of El: El in Ancient South Arabic Religion', ZAW 82 (1970), pp. 206-207; P.C. Craigie, 'Helel, Athtar and Phaethon (Jes 14:12-15)', ZAW 85 (1973), pp. 223225; and M.S. Smith, 'The God Athtar in the Ancient Near East and His Place in KTU 1.6.I', in Z. Zevit, et al. (eds.) Solving Riddles and Untying Knots: Biblical, Epigraphic, and Semitic Studies in Honor of Jonas C. Greenfield (Winona Lake, 1995), pp. 634-636. Other scholars have tried to make the association without recourse to South Arabian inscriptions by referencing an epithet which described 'Atttar as 'luminous', so J. Jensen, 'Helel Ben Shahar (Isaiah 14:12-15) in Bible and Tradition', in C.C. Broyles \& C.A. Evans (eds.) Writing and Reading the Scroll of Isaiah: Studies of an Interpretative Tradition, 2 vols. (Leiden, 1997), 1: 342.
}

${ }^{17}$ N. Wyatt, 'Who Killed the Dragon?' AuOr 5 (1987), esp. p. 194.

${ }^{18}$ In favour of the'Attar myth as the most likely mythological background for Isa 14:12-15 are M.S. Heiser, 'The Mythological Provenance of Isa. XIV 12-15: A Reconsideration of the Ugaritic Material', VT 51 (2001), pp. 354-369; Day, Yahweh and the Gods and Goddesses of Canaan, pp. 171-174; and J.L. Cooley, Poetic Astronomy in the Ancient Near East: The Reflexes of Celestial Science in Ancient Mesopotamian, Ugaritic, and Israelite Narrative (Winona Lake, 2013), pp. 241245.

${ }^{19}$ D. Pardee, 'Ugaritic Myths', in W.W. Hallo \& K.L. Younger (eds.) Context of Scripture: Canonical Compositions from the Biblical World (Leiden, 2003), p. 242. 
Article accepted for publication with Vetus Testamentum.

After 'Attar abandoned Ba'al's throne he was sent to rule over the 'arș. In Ugaritic, and according to some commentators, in Ancient Hebrew too, ${ }^{20}$ 'arș can have a dual referent, reflecting both conceptions of 'earth', 'world', 'land', 'country', and 'ground'; but also the 'underworld', the realm of the dead. ${ }^{21}$ In the case of the domain of 'Attar in the Ba'al cycle, if 'arș is preferred here to recall the underworld, then the connection of this myth to that of the hêlel ben-šahar in the Isaiah pericope would indeed be strengthened. Yet this would be to interpret this episode of the Ba'al cycle in light of Isa 14:12-15, in order to provide a parallel in the Ugaritic myth with which to interpret the Isaiah passage - a rather circular method. In the Ba'al cycle, a number of different gods vie for kingship: in the case of Yamm and Ba'al, the competition seems to be for the same kingship, hence the conflict; while 'El, 'Attar and Môt seem to exercise kingship in their own spheres. These spheres are not always immediately identifiable; debate has raged, for example, concerning the abode of 'El.22 However, if we make 'Attar's sphere the underworld, we must displace Môt, surely the more likely god to be associated with this realm. Thus scholars of the Ba'al cycle have tended to take 'arș in the 'Attar episode according to its more common meaning of 'earth'. For those who interpret Ba'al as king of the earth, this creates a problem: A. Caquot, M. Sznycer and A. Herder, for example, take 'Attar's rule over the 'arș to denote rulership over a particular land, in contrast to Ba'al's more general rule. ${ }^{23}$ However, a formal claim to kingship of the earth is not found in any of the statements concerning Ba'al's kingship. D. Pardee, noting the very specific terminology utilized in this passage (so 'Attar climbs, 'ly, Mount Zaphon to take the throne, and descends, yrd, when abandoning that throne), suggests interpreting 'Attar's role as king of the flatlands, in contrast to Ba'al's abode in the mountain of Zaphon. ${ }^{24}$ The latter exploits the links between mountain tops and storm clouds with Ba'al's role as provider of rain; the former with the understanding of 'Attar as a god of irrigation, a possible understanding of the etymology of the name 'Attar

\footnotetext{
20 So M. Dahood, Psalms 1-50 (Garden City, 1966), p. 106; and N.J. Tromp, Primitive Conceptions of Death and the Nether World in the Old Testament (Rome, 1969), pp. 23-46; and reflected by the NRSV translation of 'āreș as 'underworld' in Jer 17:13.

${ }^{21}$ See P.S. Johnston, Shades of Sheol: Death and the Afterlife in the Old Testament (Leicester, 2002), p. 49 , n. 4.

22 See for example the discussion in M.S. Smith, The Ugaritic Baal Cycle. Vol. I: Introduction with Text, Translation and Commentary of KTU 1.1-1.2 (Leiden, 1994), pp. 225-230.

${ }^{23}$ A. Caquot, M. Sznycer \& A. Herder, Textes Ougaritiques. Tome 1: Myths et légendes (Paris, 1974), p. 258.

${ }^{24}$ Pardee, 'Ugaritic Myths', p. 269, n. 250; this may also be referred to in $K T U^{3} 2.3 .17-18$.
} 
Article accepted for publication with Vetus Testamentum.

itself.25 This would explain why 'Attar's attempt to fulfil the function of Ba'al falls short, since in the Levant irrigation is unable to adequately substitute for a shortage of rainfall. ${ }^{26}$ It might also be understood to metonymically reflect the common Semitic ${ }^{27}$ pairing of šmym //'rș, reflecting the totality of the observable world, and associating the role of Ba'al, the $r k b$ 'rpt, 'cloud rider', with the former domain; and 'Attar with the latter. In any case, the fate of 'Attar to rule over the earth in the Ba'al cycle is hardly a fate similar to that described in Isa 14:15.

A further difficulty in the association of the 'Attar episode with Isa 14:12-15 once again rests in the conflation of different traditions: there actually was a god of the dawn at Ugarit, Šahru (cognate with Hebrew šahar); while, as we have seen, 'Attar is more usually recalled as a god of irrigation. Šahru and his brother Šalimu were the sons of 'Atirat and Rahmiya (KTU3 1.23.53); 'Attar was the son of 'Atirat and 'El (KTU3 1.6.1.4346; $K T U^{3}$ 1.16.5.25-28). It is simply not correct to say that 'Attar was ben-šahar, as the association of this god with hêlēl ben-šahar requires. Despite the scholarly ferment, a specific parallel to the tale of hêlēl ben-šaḥar is not provided by the Ugaritic traditions concerning 'Attar.

A final attempt to propose an ancient Near Eastern source for the imagery in Isa 14:12-15 looks to Mesopotamian texts, most commonly to (iii) the Akkadian myth of Ištar's Descent to the Netherworld. ${ }^{28}$ The Hebrew term hêlēl is a hapax legomenon, and several different interpretations have been proposed to deal with it. One of these interpretations derives hêlēl from the Hebrew verb hll, 'to shine', a cognate of which appears in Akkadian as ellu. The feminine form of this Akkadian word is elletu, which also occurs as an epithet for the goddess Ištar. ${ }^{29}$ Ištar, goddess of love, fertility and war, could also be associated with the planet Venus, in this context sometimes known by the

\footnotetext{
25 See ibid., p. 247, n. 48; p. 269, n. 245.

${ }^{26}$ Ibid., p. 269, n. 250.

${ }^{27}$ See Y. Avishur, Stylistic Studies of Word-Pairs in Biblical and Ancient Semitic Literatures (Neukirchen-Vluyn, 1984), pp. 603-604: this pair occurs in Hebrew, Ugaritic, Phoenician, Aramaic and Akkadian texts.

${ }^{28}$ For affirmation of Babylonian conceptions as a general source of the mythological background of Isa 14:12-15, see G.W. Wade, The Book of the Prophet Isaiah (London, 1911), pp. 100-101; G.B. Gray, A Critical and Exegetical Commentary on the Book of Isaiah (Edinburgh, 1912), p. 256; and J. Skinner, The Book of the Prophet Isaiah, Chapters I-XXXIX (Cambridge, 1951), p. 122.

${ }^{29}$ See R.L. Alden, 'Lucifer, Who or What?', BETS 11 (1968), p. 36.
} 
Article accepted for publication with Vetus Testamentum.

name Ninsianna. ${ }^{30}$ Thus a certain strand of the scholarship has equated hêlēl ben-šaḥar with the Mesopotamian goddess, and the mythological referents of Isa 14:12-15 to the Neo-Assyrian tale associated with her. The tablet in question relates the descent of Ištar to the Netherworld to visit her sister Ereškigal, from where she was subsequently prevented from leaving. Fertility back on earth was affected by her absence and eventually Ea intervened to persuade Ereškigal to release her sister. ${ }^{31}$ The seasonal associations of this myth are obvious; it has also been suggested that the myth served to explain the periodic disappearance and reappearance of the planet Venus in the night sky. ${ }^{32}$ While this may be so, on reflection it does not really provide a good parallel to Isa 14:12-15. Ištar's descent is not preceded by an act of hubris, and while she does remain for a time in the Netherworld, she is eventually released. Ištar is a female goddess; hêlēl ben-šahar is grammatically masculine and would therefore most likely describe a male figure. Moreover, while in Mesopotamian tradition 'Ištar' could designate Venus, it was only as the evening star that the planet was considered to be a goddess - the morning star was understood to be a male god. ${ }^{33}$ Grammatical case aside, this observation makes the ben-šaḥar, 'the son of dawn', rather unlikely as a reference to a Mesopotamian female goddess. Vectors of transmission must also be taken into consideration: Ištar's descent was not widely copied in antiquity, and we have but one exemplar, from the archives at Nineveh. ${ }^{34}$ It has been common among some interpreters to treat Isa 14:1215 as if it were a historicization of the seasonal myth trope, thus M.A. Sweeney depicts the passage as

an attempt to satirize the death of Sargon II in relation to one of the most fundamental patterns of ancient Near Eastern religiosity: the death and rebirth of the fertility god or

\footnotetext{
${ }^{30}$ J. Black \& A. Green, 'Inana (Ištar)', in Gods, Demons and Symbols of Mesopotamia: An Illustrated Dictionary (London, 1992), p. 109.

${ }^{31}$ For the text and translation of the myth see P. Lapinkivi, The Neo-Assyrian Myth of Istar's Descent and Resurrection (SAA, 6; Helsinki, 2010).

${ }^{32}$ For example C. Hostetter, Star Trek to Hawa-i'i: Mesopotamia to Polynesia (San Luis Obispo, 1991), p. 53.

${ }^{33}$ J. Black \& A. Green, 'Ishtar', in P. Bienkowski \& A. Millard (eds.) Dictionary of the Ancient Near East (Philadelphia, 2000), p. 156.

${ }^{34}$ Admittedly the older Sumerian myth of the descent of the goddess Inanna to the Netherworld is better attested; the shorter Akkadian tale of Ištar is related to this earlier text as part of the 'modernization, simplification, expansion and corruption' of earlier texts which took place in the second and first millenniums BCE; see B.R. Foster, Akkadian Literature of the Late Period (Münster, 2007), p. 100.
} 
Article accepted for publication with Vetus Testamentum.

goddess, which govern the dry and rainy seasons of the land, and thus determines the seasons of fertility and lack thereof. ${ }^{35}$

Yet though Isa 14:12-15 does portray a descent to the underworld, ${ }^{36}$ in the textual witness this is demonstrably not accompanied by a correlated 'death' and decline in the fertility of the external world. Unlike Ištar's descent, the hêlēl ben-šaḥar does not return from the underworld - and a return is the crux of any mythic trope within the context of the seasonal cycle of fertility. Ištar's descent to the Netherworld saw a decline in fertility; her return restored it. In the much more elaborated Sumerian myth upon which this Akkadian tale is based, the goddess Inanna's stay in the Netherworld ended only when her husband Dumuzi took her place, spending half of every year there. During this time Inanna's powers waned and fertility on earth was affected, a cycle which approximates the shift in the seasons. ${ }^{37}$ Central to both these accounts is the return: of the goddess (or her husband) from the underworld and hence of the fertile season. The Neo-Assyrian myth of Ištar's Descent to the Netherworld, and the seasonal myth cycle in general, does not provide good analogy to Isa $14: 12-13 .{ }^{38}$

Arguably what all these interpretations have in common is a governing methodological decision to interpret hêlēl ben-šaḥar as the planet Venus, and then to approach the ancient Near Eastern literary corpus under this assumption, entailing a search for a suitable referent from the literature (so Phaëton, 'Attar and Ištar, figures who have all at times been associated with Venus), followed by a process of smoothing over the resulting inconsistencies to make the parallel fit. But as we have seen, none of the proposed traditions really work as good explanations for the themes and ideas expressed in Isa 14:12-15. If the reference to Venus supposed to be apparent in hêlēl

35 M.A. Sweeney, Isaiah 1-39, with an Introduction to Prophetic Literature (Grand Rapids, 1996), p. 238.

${ }^{36}$ The etymology of $\check{s}^{\prime}{ }^{\prime} \hat{o} l$ is widely disputed and so far little light has been shed by comparative study. Due to the brevity of this inquiry it has not been possible to explore the semantics of še'ôl; see instead R.S. Hess, 'Going Down to Sheol: A Place Name and Its West Semitic Background', in J.G. McConville \& K. Möller (eds.) Reading the Law: Studies in Honour of Gordon J. Wenham (LHBOTS, 461; London, 2007), pp. 246-253. In the context of Isa 14:12-15, I have understood še'ôl as a poetic term for the place where the dead reside (ibid., p. 247).

${ }^{37}$ For a translation of this Sumerian text, see J. Black, G. Cunningham, \& E. Robson, The Literature of Ancient Sumer (Oxford, 2004), pp. 68-76.

${ }^{38} \mathrm{The} \mathrm{Ba}$ 'al cycle has also been interpreted as an ancient effort to explain seasonal variation; see especially J.C. de Moor, The Seasonal Pattern in the Ugaritic Myth of Balu (Kevelaer, 1971). Arguably the reason why the death of Ba'al himself has not been related to Isa 14:12-15 is only because of the necessity of the astral referent which seems to be implied by hêlēl ben-šahar. 
Article accepted for publication with Vetus Testamentum.

ben-šahar is ignored, the associations between the figure in Isaiah and these figures from extra-biblical textual traditions lose any real association. Yet despite the prevalence of this interpretation of hêlēl ben-šaḥar in modern translations, the meaning 'Venus' is by no means the necessary or even the most obvious reading of the phrase.

\section{Who or What is hêlēl ben-šaḥar?}

To the minds of many previous scholars tasked with interpreting the meaning of hêlēl ben-šahar, foremost among the problems is the etymology of the hapax legomenon hêlèl. What exactly is being described here as ben-šaḥar, 'son of the dawn'? Early commentators, referring the hapax to Arabic hilalun, 'new moon', questioned the Masoretic pointing of the word, suggesting that hyll instead be pointed as hilāl, to give the meaning 'new moon'.39 The resultant nonsensical translation of 'new moon, son of the dawn' necessitated further textual emendation, with šhr, 'dawn', altered to read *śhr, a root unattested in Biblical Hebrew but which in Arabic, Aramaic, Syriac and Ethiopic refers to the moon (god). ${ }^{40}$ The altered text of Isa 14:12 would thus give the reading 'new moon, son of the old moon': semantically logical at least, but favouring the emendation of a well-attested Hebrew word, šahar, for a word which is unattested in the Hebrew language.

An alternative proposal sees hêlēl referred to the Hebrew verb hll, 'to shine' (e.g., Isa 13:10; Job 29:3, 31:26, 41:10; cf. Arabic halla, Ugaritic hll and Akkadian ellu). ${ }^{41}$ Thus the phrase would give the meaning 'shining one, son of the dawn' (cf. NET). This seems a plausible solution, but it does not really solve our problem of the meaning of the phrase. What is at issue here is not so much a problem of translation but of interpretation. Who

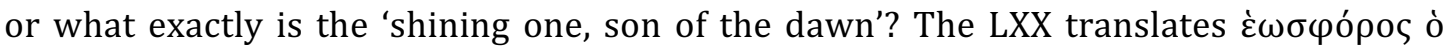
$\pi \rho \omega i$ ' $\alpha \alpha \alpha \tau \varepsilon \lambda \lambda \omega v$, 'bringer of the morn, who used to rise early in the morning', while the Vulgate has Lucifer, qui mane oriebaris, 'Lucifer [sc. Venus], who used to rise early in the morning' - the interpretation which has dominated the subsequent translations. What has proven to be so attractive to scholars here is the linking of Isaiah's phraseology to a mythic past, a mythological explanation for a physical spectacle, thus G.B. Gray:

\footnotetext{
${ }^{39}$ For the alternative suggestion that hêlēl may refer to the old moon, see Koenig, 'Lucifer', p. 479; and Gray, A Critical and Exegetical Commentary on the Book of Isaiah, p. 256. The resultant translation of 'old moon, son of the dawn' is similarly implausible.

${ }^{40}$ So L. Koehler \& W. Baumgartner, The Hebrew and Aramaic Lexicon of the Old Testament, 5 vols. (trans. and ed. M.E.J. Richardson; Leiden, 1994), I: 248.

${ }^{41}$ P. Grelot, 'Sur la Vocalisation de hyll (Is. XIV 12)', VT 6 (1956), pp. 303-304; but see already S.A. Hirsch, 'Isaiah 14:12', JQR 11 (1920/21), p. 197.
} 
Article accepted for publication with Vetus Testamentum.

The natural phenomenon which gave rise to the myth, and still affects the phraseology of this passage, may be the contrast between the brilliance of a star, such as Venus, at the seasons when it is apparent, and its total disappearance at other seasons. ${ }^{42}$

But already J. Mauchline had noted problems with this association: 'But the morning star fades out, it does not fall from heaven'.43 In the 1920s and 1930s two scholars made an alternative suggestion for the referent of hêlēl ben-šahar, though rarely acknowledged by subsequent interpreters. For S.A. Hirsch,

[t]here is only one heavenly body which can serve as an emblem of the aspirations of an warlord of the world - and that is the sun. The sun is the child of the dawn, born after the darkness of the night. ${ }^{44}$

H.G. May agreed, arguing that hêlēl ben-šaḥar was a reference to the sun of the winter solstice. ${ }^{45}$ More recently this argument has been renewed by K. Spronk, based on his structural comparison of Isa 14:12-15 with Isa 13:10-11, where 'the sun will be dark at its rising' (v. 10) and 'the pomp of the arrogant' will be ended (v. 11). ${ }^{46}$ Certainly elsewhere in the Hebrew Bible, šemeš, 'sun', could be correlated with šaḥar, 'dawn' (e.g. Song 6:10; Job 31:26). In Job 3:9, 'ā̄'appê-šaḥar, literally 'eyelids of the morning' (RSV; NRSV) but sometimes translated alternatively as 'dawning of the day' (KJV), might also be taken as a reference to the sun, if 'ap̄'appê, 'eyelashes', be understood as a metaphor for the sun's rays (so NIV). ${ }^{47}$ Nor did the specific terminology šemeš, or alternatively heres or hammā, 'sun', necessarily have to be employed in order to express this semantic range. As a case in point, in the creation account of Genesis 1 God engages in acts of creation which require the reader to appreciate that the sun is being established ('Let there be light... lights in the expanse of the heavens... two great lights, the greater light to rule the day and the lesser light to rule the night') without ever making recourse to these terms. ${ }^{48}$ Tellingly, hll is not taken to refer to Venus elsewhere in the Hebrew Bible,

\footnotetext{
${ }^{42}$ Gray, A Critical and Exegetical Commentary on the Book of Isaiah, p. 255.

43 J. Mauchline, Isaiah 1-39 (London, 1962), p. 140 (italics in original).

${ }^{44}$ Hirsch, 'Isaiah 14:12', p. 198.

${ }^{45}$ H.G. May, 'Some Aspects of Solar Worship at Jerusalem', ZAW 14 (1937), pp. 269-80; idem, 'The Departure of the Glory of Yahweh', JBL 11 (1920/21), pp. 187-199.

${ }^{46} \mathrm{~K}$. Spronk, 'Down with Hêlēl! The Assumed Mythological Background of Isa. 14.12', in M. Dietrich \& I. Kottsieper (eds.) 'Und Mose schrieb dieses Lied auf': Studien zum Alten Testament und zum Alten Orient: Festschrift für Oswald Loretz (AOAT, 260; Münster, 1998), pp. 717-726.

47 Perhaps following M. Dahood, Ugaritic-Hebrew Philology: Marginal Notes on Recent Publications (Rome, 1965), p. 41.

${ }^{48}$ See also Job 31:26, 37:21; Ps 136:7. That Hebrew 'or, 'light', could be employed with the meaning 'sun' may be instructive with regard to Isa 14:12 in light of E.Y. Kutscher's suggestion
} 
Article accepted for publication with Vetus Testamentum.

while in Mishnaic Hebrew it is the noun nôgah, Biblical Hebrew 'brightness', which came to indicate Venus. With regards to Isa 14:12-15, to interpret the 'shining one, son of the dawn' as the sun takes seriously both the attribution ben-šaḥar to hêlēl-for what is the sun, if not the child of the morning? - and the preceding statement of v. 12, that the hêlēl ben-šaḥar has fallen from heaven: unlike Venus, which fades from view, the sun may literally be observed as it travels through the sky during the course of the day and beneath the horizon at nightfall. Moreover, the translation of the LXX, as $\dot{\varepsilon} \omega \sigma \varphi$ ó $\rho$ os ò $\pi \rho \omega \grave{i} \alpha \dot{\alpha} \alpha \tau \varepsilon^{\lambda} \lambda \lambda \omega v$, 'bringer of the morn, who used to rise early in the morning', perfectly fits an interpretation of the sun as the referent of hêlēl ben-šahar: surely more so than any star, it is the sun which portents the dawn.

According to May, the hêlēl ben-šaḥar should be taken as a reference to the sun, but he specifically interpreted the descent of this sun to the underworld in Isa 14:12 in terms of the 'seasonal crisis' of the winter solstice 49 - ultimately he still understood the imagery of the Isaiah passage to stem from an Israelite reinterpretation of the seasonal myth trope. ${ }^{50}$ Spronk, meanwhile, based his argument for a solar interpretation of the hêlēl ben-šaḥar on the basis of an inner-biblical comparison, in so doing making light of the Ugaritic associations which can be found throughout Isa 14:12-15. However, had May or Spronk turned to alternative conceptions of the sun as expressed in the ancient Near East, they might better have understood the themes that underlie Isa 14:12-15, where the sun is not recalled in relation to its seasonal, and that is, its fertile, aspect, but rather makes use of the Ugaritic image of the chthonic sun, dispenser of justice in the ancient world. Indeed, we shall see that this mythological background better fits our passage than any other of the ancient Near Eastern contexts that have previously been proposed for Isa 14:12-15.

\section{The Chthonic Sun in the Ancient Near East}

that in Isa 13:10 the rather uncommon verb hll be taken as a substitution for the more common 'or (see E.Y. Kutscher, The Language and Linguistic Background of the Isaiah Scroll [Leiden, 1974], p. 216).

${ }^{49}$ May, 'Some Aspects of Solar Worship at Jerusalem', p. 273; cf. W.C. Graham \& H.G. May, Culture and Conscience: An Archaeological Study of the New Religious Past in Ancient Israel (Chicago, 1936), pp. 98, 130.

${ }^{50}$ This type of seasonal or natural explanation is also complicit with the minority interpretation that connects the hêlēl ben-šahar to the appearance of a comet in the night sky, so D. Etz, 'Is Isaiah xiv 12-15 a Reference to Comet Halley?' UF 36 (1986), pp. 131-146; and M.A. Van Der Sluijs, 'Hll: The Lord of the Sickle', JNES 88 (2009), pp. 269-282. 
Article accepted for publication with Vetus Testamentum.

That the Mesopotamian sun-god Šamaš was intimately associated with death and the underworld is well established. The Great Hymn to Šamaš, for example, connects the daily course of the sun in the sky to the sun's role as a god of justice, from whose rays no secret may remain hidden - but just as none upon earth can hide from the sun, so too the dead at night. At night it was thought that Šamaš had travelled to the underworld to judge the dead, so

[There is none] but you [sc. Šamaš] who goes down to the deep,

[...] you blaze abroad the judgements on the criminal and law-breaker.

[...] You dismiss (to the underworld) the rogue who is surrounded [...]

You bring up from the underworld river him entangled in a lawsuit. [...] $]^{51}$

Thus in Mesopotamia Šamaš had a dual role: he was both 'Shepherd of that beneath, keeper of that above'.52

In Levantine religion too, it has been recognized that the sun could be connected with justice and judgement. For example, some commentators have sought to reconcile the apparent incongruity between the two sections that make up Psalm 19 - vv. 1-7, a hymn to the sun, and vv. 8-15, in praise of the glory of Torah - by referring to the sun of vv. 1-7 in the context of an ancient Near Eastern motif for justice and so a preparation for the theme of Torah in vv. 8-15. What is less recognized is that the sun could also be recalled not just as a motif for justice on earth, but in a chthonic sense. While a few commentators have previously noted this dual role, ${ }^{53} \mathrm{O}$. Wikander has recently provided a full reexamination of the chthonic characteristics of the sun-goddess in Ugaritic religion. In his study Wikander asks how the concepts of death, drought and the sun were related at Ugarit, providing a wealth of examples of the sun in the role of 'psychopomp', conductor of the deceased to the place of the dead, before employing the conceptual association between death and sun to explicate certain biblical texts. ${ }^{54}$

\footnotetext{
${ }^{51}$ For the translation see W.G. Lambert, 'The Great Hymn to Shamash', in Babylonian Wisdom Literature (Oxford, 1960), pp. 121-138 (ll. 57-62).

52 Ibid., l. 33.

${ }^{53}$ See especially J.F. Healey, 'The Sun Deity and the Underworld: Mesopotamia and Ugarit', in B. Alster (ed.) Death and Mesopotamia: Papers Read at the XXXVIe Rencontre Assyriologique International (Copenhagen, 1980), pp. 239-242; for further bibliography see 0. Wikander, Drought, Death and the Sun in Ugarit and Ancient Israel: A Philological and Comparative Study (Winona Lake, 2014), pp. 6-9.

${ }^{54}$ Wikander treats the story of Elijah and the great drought in 1 Kings 17-18, as well as passages from the books of Isaiah, Jeremiah, Hosea, Joel, Malachi, Psalms, and Job. Selections from the Deuterocanonical literature are also reviewed, namely from the Wisdom of Solomon and Ben
} 
Article accepted for publication with Vetus Testamentum.

The connection between the Ugaritic sun-goddess Šapšu to the underworld can be found in various types of Ugaritic literature. $K T U^{3} 1.6 .6$ is a hymnal passage that occurs in the concluding lines of the Ba'al-Mot episode in the Ba'al cycle. Here Šapšu is declared to rule the 'ancestral spirits', the rp'um: ${ }^{55}$

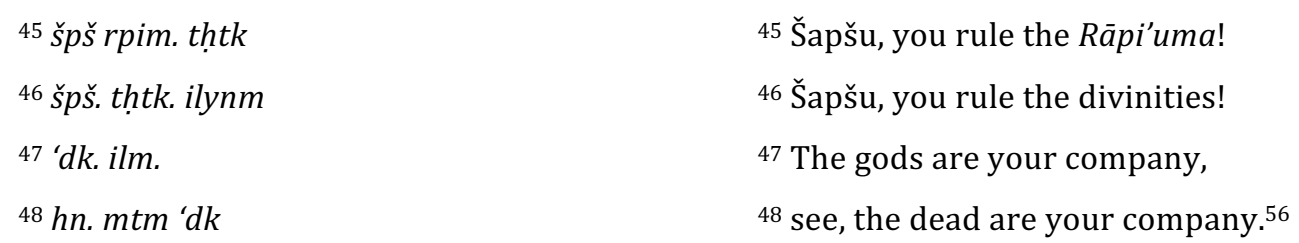

Another text, $K T U^{3} 1.161$, presents Šapšu as one of the main connections between the lands of the living and the dead. There is some debate as to whether this text should be considered a funerary lament ${ }^{57}$ or a ritual text describing a ceremony of invocation and sacrifice to the dead in order to bring about blessing for the king and city: ${ }^{58} 11.44-48$ are too broken to allow for full understanding but nevertheless make mention of Šapšu alongside the dead and the rp'um; 1l. 20-26 have been interpreted as an incantation about going down to the underworld and spoken by Šapšu herself, who directly participates in the ritual. ${ }^{59}$ Here Šapšu plays an explicit role in connection with the cult of the dead, calling to the ancestors (špš tșh) and describing going down to the underworld and descending to the dust ('arș rd. w.špl. 'pr). ${ }^{60}$

Šapšu seems to have had a particular connection with the chief Ugaritic deity of the underworld, Rašap. ${ }^{61}$ The incantation text $K T U^{3} 1.100$ tasks Šapšu with delivering a message to Rašap (1l. 30-31); while in the famous astrological report $K T U^{3} 1.78$, which apparently describes a solar eclipse, Šapšu is understood to have descended to the underworld and Rašap described as her 'gatekeeper', opening the gates of the

Sira; see Wikander, Drought, Death and the Sun in Ugarit and Ancient Israel, pp. 131-221. Wikander does not include Isa 14:12-15 among his chosen texts.

55 See above, n. 13.

${ }^{56} K T U^{3}$ 1.6.6.45-48.

${ }^{57}$ So Wikander, Drought, Death and the Sun in Ugarit and Ancient Israel, p. 77; and W.T. Pitard, 'The Ugaritic Funerary Text RS 34.126', BASOR 232 (1978), 65-75.

${ }^{58}$ See A. Caquot, 'La tablette RS 24.252 et la question des rephaïm ougaritique', Syria 53 (1976), pp. 245-304. M. Pope, 'Notes on the Rephaim from Ugarit', Memoirs of the Connecticut Academy for the Arts and Sciences 19 (1977), pp. 163-187, understands the text to describe a seven day ceremony for the dead related to the kispu ritual of Mesopotamia.

${ }^{59}$ So Pope, 'Notes on the Rephaim from Ugarit'; de Moor, 'Rāpi'ūma - Rephaim'; and D. Pardee, Ritual and Cult at Ugarit (Leiden, 2002), p. 86.

${ }^{60} \mathrm{KTU}^{3} 1.161 .19-20$.

61 On this deity see Pardee, Ritual and Cult at Ugarit, pp. 282-283. 
Article accepted for publication with Vetus Testamentum.

underworld to allow the sun to enter. ${ }^{62}$ Here perhaps most explicitly, this underworld aspect of Šapšu is shown to have stemmed from the notion that at night (and perhaps also during a solar eclipse) the sun had travelled from west to east through the subterranean realm of the dead, taking with her the spirits of the deceased and offerings for those already dwelling below, ${ }^{63}$ therefore ascribing to the goddess great power over both the dead and their realm. Note that Šapšu in the Ba'al cycle, unlike the other deities, does not have a fixed abode, which Pardee relates to her constant circulation between the heavens and through the underworld. ${ }^{64}$ In her chthonic aspect Šapšu was sometimes known as Šapšu-Pagri, 'Šapšu-of-the-corpse',65 a manifestation of the sun deity that explicitly expressed her role in enabling corpses to gain access to the underworld.66

\section{Isa. 14:12-15 - Reflections of the Chthonic Sun?}

We have already noted that the role of the sun as bringer of justice has been utilized in explication of some difficult biblical passages; given the increasing 'solarization' of Yahweh and of Israelite religion in general, ${ }^{67}$ might the idea of a chthonic sun also have been present in the religion of ancient Israel? Some critics have been quite skeptical with regards to the connection between the sun and underworld at Israel, ${ }^{68}$ while others have provided a more positive assessment. In particular G. Eberhardt has argued that Yahweh's increase in power over the sphere of the dead can be correlated to his increasing 'solarization'.69 Whatever the truth of this, the mythic topos of the chthonic

62 Ibid., p. 133, n. 15.

${ }^{63}$ So A. Caquot, 'La divinité solaire ougaritique', Syria 36 (1959), pp. 90-101; de Moor, 'Rāpi'ūma - Rephaim', p. 330; Healey, 'The Sun Deity and the Underworld', p. 240; J.-M. Husser, 'Shapash psychopompe et le pseudo hymne au soleil (KTU 1.6 vi 42-53)', UF 29 (1997), pp. 227-243; and Wikander, Drought, Death and the Sun in Ugarit and Ancient Israel, p. 2.

${ }^{64}$ Pardee, 'Ugaritic Myths', p. 271, n. 263.

${ }^{65}$ See for example the deity list $K T U^{3} 1.102 .12$; and the sacrificial text $K T U^{3} 1.39 .12,17$.

${ }^{66}$ See Pardee, Ritual and Cult at Ugarit, p. 284.

${ }^{67}$ On the 'solarization' of Israelite religion, see e.g. M.S. Smith, 'The Near Eastern Background of Solar Language for Yahweh', JBL 109 (1990), pp. 29-39; P.-E. Dion, 'YHWH as Storm-god and Sungod: The Double Legacy of Egypt and Canaan as Reflected in Psalm 104', ZAW 105 (1991), pp. 4371; and Day, Yahweh and the Gods and Goddesses of Canaan, pp. 151-163.

${ }^{68}$ In particular B.B. Schmidt, Israel's Beneficent Dead: Ancestor Cult and Necromancy in Ancient Israelite Religion and Tradition (FAT, 11; Tübingen, 1994), pp. 84-88.

${ }^{69} \mathrm{G}$. Eberhardt, JHWH und die Unterwelt: Spuren einer Kompetenzausweitung JHWHs im Alten Testament (FAT, 2:23; Tübingen, 2007); see also W.D. Barker, “'And Thus You Brightened the Heavens...” A New Translation of KTU 1.5 I 1-8 and its Significance for Ugaritic and Biblical 
Article accepted for publication with Vetus Testamentum.

sun as found at Ugarit can be usefully employed to provide context for the mythological referents of Isa 14:12-14. It takes seriously the Ugaritic allusions which we found to abound in Isa 14:13-14: the fall of the hêlēl ben-šahar to še'ôl, understood as the fall of the sun to the underworld, can be related to the perception of the sun as psychopomp realized in the Ugaritic texts. The author of Isa 14:12-15 utilized this trope, but rather than judging the dead upon arriving in še'ôl this 'shining one' does not 'rule the Räpi'uma' as at Ugarit. Instead it is the 'shining one' who is judged: 'Those who see you will stare at you and ponder over you' (v. 16); 'you are cast out, away from your grave' (v. 19). Isa 14:12-15 makes use of an ancient conception of the sun in its relation to the underworld, but subverts the traditional understanding of the sun in this realm. For all its assertions, it is only Yahweh who rules heavens, earth and underworld; the sun may traverse the heavens and descend to še'ôl but for the author of this Isaiah passage, only Yahweh has power in either realm.

Thus a traditional understanding of the chthonic sun underpins Isa 14:12-13: but this image is subverted, made complicit with the authors aim of describing the downfall and hubris of those who would be unfaithful, personified in the appended poem vv. 4b-11 as the 'oppressor' and, for the redactor of vv. 3-4a and 22-23, ultimately as Babylon. There are two narratives at work in the poem: the downfall of the oppressor and the metanarrative that governs the imagery employed to describe this downfall, of the sun and its nightly travels to $\check{S}^{\prime}{ }^{\prime} \hat{o} l$. While recognizing that the sun is the referent of hêlēl ben-šaḥar has obvious implications for our understanding of this metanarrative and the imagery it engenders, it also works on the former, more obvious narrative level. In the ancient Near East, royal ideology could also possess a cosmological dimension; in Babylon and Assyria solar imagery was frequently employed as a motif for kingship, a connection governed by association, so E. Frahm:

[T] he sun is by far the brightest heavenly body. Its radiance, called in Akkadian birbirru, melamnu, namriru, and šalummatu, is much more powerful than that of the moon, the planets, and the stars - just as the power of the king was supposed to surpass that of every living being. ${ }^{70}$

Frahm has provided a recent exploration of the solar motifs that were frequently utilized in Mesopotamian kingship ideology; expressed in rituals, epithets, and art, the

Studies', UF 38 (2006), pp. 41-52; and Wikander, Drought, Death and the Sun in Ugarit and Ancient Israel, pp. 131-221.

${ }^{70}$ E. Frahm, 'Rising Suns and Falling Stars: Assyrian Kings and the Cosmos', in J.A. Hill et al. (eds.) Experiencing Power, Generating Authority: Cosmos, Politics, and the Ideology of Kingship in Ancient Egypt and Mesopotamia (Philadelphia, 2013), p. 120. 
Article accepted for publication with Vetus Testamentum.

sun could be employed to underscore the permanence and continuity of the monarch's reign, just as the sun would rise and fall in perpetuity. In this context, Frahm speculates that the hêlēl ben-šahar, though obviously Canaanite in mythological orientation, may be read as a deliberate critique of the cosmological foundation of Mesopotamian royal ideology, though 'in the official discourse of their own sphere, Assyrian kings were of course never portrayed as falling stars. Instead... they resembled the rising sun, and they implemented their status as "living images" of the sun-god, the patron of justice, through elaborate rituals.' ${ }^{71}$ Frahm understands hêlēl ben-šaḥar according to the traditional conception of this enigmatic referent as a 'star'; I have attempted to show in this analysis that this is not the only, or even the most obvious, reading of the phrase. Instead the motifs employed seem to fit within the context of the sun as psychopomp that we found in the Ugaritic texts; Frahm's portrait of the solar ideology that underpinned Mesopotamian kingship shows that the image of the sun works on this narrative level too: as a critique of the 'oppressor', in vv. 3-4a and 22-23 understood to refer to Babylon but as the later commentators whom we met earlier have shown, perhaps referring to Assyria instead. Whichever of these world powers is understood, the sun as royal image can further explicate the motifs that govern Isa 14:12-15. Both images at play in this passage, the sun as psychopomp and the sun as a royal Mesopotamian motif, work together in a complex of associations: this tale of a tyrant who would be king is underpinned by a further narrative layer concerned with the impotence of the sun-god who would be Yahweh. Neither have efficacy in the realm of the living or the dead; both are brought down and humbled.

This paper has sought to provide an alternative answer to the question of the mythological referents of Isa 14:12-15. Noting the problems with previous proposals, nevertheless it was affirmed that the passage seemed to provide strong associations with notions commonly expressed in Ugaritic texts, though no Ugaritic myth thus far suggested had fully accounted for the ideas articulated in the Isaiah text. Turning to the interpretation of the mysterious figure of v. 12, it was argued that the hêlēl ben-šahar, literally the 'shining one, son of the dawn', might better be identified as a reference to the sun rather than to the traditional understanding of this as the planet Venus, complicit with a 'seasonal' interpretation of the passage. This opened up a hitherto overlooked relation to the conception of the chthonic sun as found in Ugaritic texts; it was proposed that the author of Isa 14:12-15 was aware of these associations between

\footnotetext{
${ }^{71}$ Ibid., pp. 111-112.
} 
Article accepted for publication with Vetus Testamentum.

sun and underworld, and utilized them in the production of his passage. Thus the author could present an image of the sun soaring in the heavens before falling to the underworld, but unlike the Ugaritic Šapšu this sun had no authority over either territory. Instead the text descends into an ironic lament for this pitiful figure, totally subsumed under the power of Yahweh. The dual imagery of the sun as psychopomp and the sun as Mesopotamian king work together to further affirm the fall of the hubristic oppressor established already in vv. 4b-11. 